\title{
Screening of antigenemia and isolation of Cryptococcus neoformans and C. gattii from cloaca and crop of birds in the state of Paraná, Brazil ${ }^{1}$
}

\author{
Camile Lugarini2*, Larissa A.Z. Condas ${ }^{3}$, Grazielle C.G. Soresini ${ }^{4}$, Renata C.F. \\ Santos $^{3}$, Marisol D. Muro ${ }^{5}$, Margaret Ono ${ }^{5}$, Marconi R. Farias ${ }^{4}$ and Fabiano \\ Montiani-Ferreira ${ }^{3}$
}

\begin{abstract}
Lugarini C., Condas L.A.Z., Soresini G.C., Santos R.C.F., Muro M.D., Ono M., Farias M.R. \& Montiani-Ferreira F. 2008. Screening of antigenemia and isolation of Cryptococcus neoformans and C. gattii from cloaca and crop of birds in the state of Paraná, Brazil. Pesquisa Veterinária Brasileira 28(7):341-344. Departamento de Medicina Veterinária, Rua dos Funcionários 1540, Juvevê, Curitiba PR 80035-050, Brazil. E-mail: camilelug@gmail.com

Cryptococcus neoformans and C. gattii are associated with dry bird excreta but rarely recovered from birds' digestive tract. The objective of the present study was (1) to verify the existence of $C$. neoformans and $C$. gattii in crop and cloaca of wildlife and captivity birds hypothesizing about a possible primary source of this yeast in the excreta, and (2) to determine the fungi's invasive capability in avian species through latex agglutination. For that purpose, 172 cloacal and 77 crop samples of domestic pigeon, Passerine, and Psittacine birds were collected. None of these samples was positive, suggesting that the yeast is not saprobiotic in the digestive tract of these birds. Only one out of 82 serum samples collected from pigeons and Psittacine birds was positive (title 1:2) showing that Cryptococcussp. probably has a low invasive capability in birds, and is thus considered only a dry excreta colonizer.
\end{abstract}

INDEX TERMS: Ecology, birds, yeast, Cryptococcus neoformans, Cryptococcus gattii.

RESUMO-- [Antigenemia e tentativa de isolamento de Cryptococcus neoformans e C. gattii a partir da cloaca e inglúvio de aves no Estado do Paraná.] Cryptococcus neoformans e $C$. gattii são frequentemente isolados de excretas de aves, entretanto ocorre pouca recuperação desse fungo a partir do trato gastrintestinal. Os objetivos desse estudo foram verificar a existência de $C$. neoformans e $C$. gattii no inglúvio e na cloaca de aves de vida livre e cativeiro,

\footnotetext{
${ }^{1}$ Received on April 15, 2008.

Accepted for publication on July 18, 2008.

2 Instituto Chico Mendes de Conservação da Biodiversidade, Parque do Bom Menino, anexo ao Núcleo de Educação Ambiental, Av. Alexandre de Moura s/n, Centro, São Luis, MA 65045-470, Brazil. *Corresponding author: camilelug@gmail.com

${ }^{3}$ Departamento de Medicina Veterinária, Universidade Federal do Paraná, Rua dos Funcionários 1540, Juvevê, Curitiba PR 80035-050, Brazil.

${ }^{4}$ Departamento de Medicina Veterinária, Pontifícia Universidade Católica do Paraná, Rodovia BR376 Km14, Costeira, São José dos Pinhais, PR 83010-500, Brazil.

${ }^{5}$ Serviço de Análises Clínicas, Hospital de Clínicas, Universidade Federal do Paraná, Av. General Carneiro 181, Curitiba, PR 80060-900.
}

avaliando uma possível fonte primária desta levedura nas excretas e determinar a capacidade invasiva do fungo em aves por meio da aglutinação em látex. Para tanto, foram coletadas 172 amostras de cloaca e 77 de inglúvio de pombos-domésticos, Passeriformes e Psittaciformes. Nenhuma amostra se mostrou positiva, sugerindo-se que o fungo não é saprobiótico do aparelho digestório destas aves. Das 82 amostras de soro colhidas a partir de pombos-domésticos e Psittaciformes, somente uma obtida a partir de pombo-doméstico se mostrou positiva (titulação 1:2), demonstrando que Cryptococcus sp. apresenta baixa capacidade invasiva em aves, sendo, portanto, considerado somente um colonizador de excretas ressequidas.

TERMOS DE INDEXAÇÃO: Ecologia, aves, fungo, Cryptococcus neoformans, Cryptococcus gattii.

\section{INTRODUCTION}

Cryptococcosis is an opportunistic fungal disease mainly caused by Cryptococcus neoformans. Immunocompro- 
mised conditions such as those found in AIDS patients, post-organ transplant surgery, or hematological malignancies constitute the main factors in the development of this disease (Mitchell \& Perfect 1995, Casadevall \& Perfect 1998).

C. neoformans was traditionally subdivided into three varieties and five serotypes: $C$. $n$. var. grubii (serotype A) (Franzot et al. 1999), C. n. var. neoformans (serotype D), serotype AD - considered a hybrid (Boekhout et al. 2001) - and C. n. var. gattii (serotypes B and C) (Franzot et al. 1999). Recently, based on its morphological, biochemical, and molecular differences it has been suggested that the C.n. var. gattii be reclassified as a new species: $C$. gattii (Know-Chung et al. 2002).

C. neoformans is found in a variety of environmental sources, although it is mainly associated with avian droppings, especially those of domestic pigeons (Kobayashi et al. 2005, Granados \& Castañeda 2005), Passerine, and Psittacine birds (Filiú et al. 2002, Abegg et al. 2006). $C$. gattii, on the other hand, is usually isolated from decaying wood (Lazéra et al. 1998, Lazéra et al. 2000, Granados \& Castañeda, 2005), although it has recently been isolated from avian droppings (Abegg et al. 2006).

Although appearing in large numbers in avian environments, Cryptococcus spp. rarely cause clinical diseases in birds, because yeast cannot either grow at the bird's temperature or survive its passage through the intestinal tract, beyond its low invasive capability in birds (Mitchell \& Perfect 1995, Casadevall \& Perfect 1998, Filiú et al. 2002). Clinical infections with a subsequent elimination of the yeast from the body by intact cell immunity can also occur (Connolly et al. 1999) and, in this case, birds can be transitory carriers of the disease (Bauwens et al. 1986, Mitchell \& Perfect 1995). In humans, clinical diseases are uncommon, but contact and sensitivization to antigens are more prevalent with antibodies detected in $20 \%$ of the adult population (Mitchell \& Perfect 1995, Malik 2003). We assumed that the same applies to pigeons and Psittacine birds. They can be in contact with the yeast and eliminate the agent spontaneously. The carrier state might precede the establishment of infection, and the positive antigenemia might confirm the contact with Cryptococcus spp.

The objective of the present study was to verify the existence of $C$. neoformans and $C$. gattii in crop and cloaca of wildlife and captivity birds hypothesizing about a possible primary source of this yeast in the excreta, and to determine the fungi's invasive capability in avian species through latex agglutination.

\section{MATERIALS AND METHODS}

A total of 77 crop and 172 cloaca samples were obtained with uretral swabs (Bionete, Biolog, São Paulo, Brazil) from Passerine, Psittacine birds, and pigeons (Table 1). Passerine, Psittacine samples were obtained from birds received in

Table 1. Cloaca, crop and serum samples obtained from domestic pigeons, Passerine, and Psittacine showing the number of samples by species

\begin{tabular}{|c|c|c|c|c|c|}
\hline Commun name & Scientific name & Order & $\begin{array}{c}\text { Number of } \\
\text { cloaca samples }\end{array}$ & $\begin{array}{c}\text { Number of } \\
\text { crop samples }\end{array}$ & $\begin{array}{c}\text { Number of } \\
\text { serum samples }\end{array}$ \\
\hline Pigeon & Columba livia & Columbiforme & 53 & 53 & 53 \\
\hline Black-throated Grosbeak & Saltator fuliginosus & Passerine & 0 & 1 & 0 \\
\hline Ultramarine Grosbeak & Cyanocompsa brissonii & Passerine & 4 & 1 & 0 \\
\hline Buffy-fronted Seedeater & Sporophila frontalis & Passerine & 10 & 0 & 0 \\
\hline Chopi Blackbird & Gnorimopsar chopi & Passerine & 7 & 0 & 0 \\
\hline Double-collared Seedeater & Sporophila caerulescens & Passerine & 7 & 0 & 0 \\
\hline Epaulet Oriole & Icterus cayanensis & Passerine & 1 & 0 & 0 \\
\hline Green-winged Saltator & Saltator similis & Passerine & 4 & 3 & 0 \\
\hline Hooded Siskin & Carduelis magellanica & Passerine & 2 & 1 & 0 \\
\hline Lined Seedeater & Sporophila lineola & Passerine & 2 & 0 & 0 \\
\hline Red-crested Finch & Coryphospingus cucullatus & Passerine & 3 & 0 & 0 \\
\hline Rufous-bellied Trush & Turdus rufiventris & Passerine & 2 & 1 & 0 \\
\hline Rufous-collared Sparrow & Zonotrichia capensis & Passerine & 2 & 0 & 0 \\
\hline Saffron Finch & Sicalis flaveola & Passerine & 11 & 1 & 0 \\
\hline Trush a & Turdus sp. & Passerine & 1 & 0 & 0 \\
\hline Uniform Finch & Haplospiza unicolor & Passerine & 1 & 0 & 0 \\
\hline Violaceous Euphonia & Euphonia violacea & Passerine & 1 & 0 & 0 \\
\hline Yellow-legged Trush & Turdus flavipes & Passerine & 2 & 0 & 0 \\
\hline Blue and yellow Macaw & Ara ararauna & Psittacine & 4 & 0 & 2 \\
\hline Orange-winged Parrot & Amazona amazonica & Psittacine & 4 & 0 & 0 \\
\hline Plain Parakeet & Brotogeris tirica & Psittacine & 4 & 4 & 0 \\
\hline Red-cappped Parrot & Pionopsitta pileata & Psittacine & 2 & 2 & 0 \\
\hline Red-tailed Amazon & Amazona brasiliensis & Psittacine & 1 & 0 & 0 \\
\hline Scaly-headed Parrot & Pionus maximiliani & Psittacine & 5 & 2 & 3 \\
\hline Turquoise-fronted Parrot & Amazona aestiva & Psittacine & 28 & 8 & 24 \\
\hline Vinaceous-breasted Parrot & Amazona vinacea & Psittacine & 11 & 0 & 0 \\
\hline Total & & & 172 & 77 & 82 \\
\hline
\end{tabular}


Centro de Triagem de Animais Silvestres (CETAS) PUCPR/ IBAMA, located in Parana state, Brazil. The pigeons were divided into two groups: 20 samples from captivity and 33 from wildlife pigeons. Psittacine birds were tranquilized with midazolam (União Química Farmacêutica Nacional, Minas Gerais, Brazil) before starting the procedure for collecting crop samples. Other samples were obtained with manual restraint only.

The samples were plated onto birdseed (Guizotia abyssinica) agar plates or tubes and incubated at $30^{\circ} \mathrm{C}$ for up to 7 days. Dark brown colonies suggestive of $C$. neoformans were then subcultivated on Sabouraud's peptone dextrose agar plates and identified as $C$. neoformans or $C$. gattii by standard morphological and biochemical methods: the ability to produce melanin in birdseed agar, cycloheximide sensitivity, thermotolerance at $37^{\circ} \mathrm{C}$, urease production, and carbon and nitrogen assimilation profiles.

Blood was collected from 29 Psittaciformes, 20 captivity pigeons, and 33 wildlife pigeons - weighing more than $300 \mathrm{~g}$ (Table 1). For this purpose, the animals were captured and manually restrained. Blood was obtained from the radial or ulnar vein, located in the medial face of their wing, centrifuged at 2000 rpm for $15 \mathrm{~min}$, and the serum was separated and stored in glass tubes at $-20^{\circ} \mathrm{C}$ till serology was done. Blood samples of Passeriformes were not collected because their size makes it impossible to obtain the serum volume necessary for carrying out the test.

Antigenemia was carried out with the Latex-Cryptococcus Antigen Detection System kit (Immuno-Mycologics, Inc., Norman, OK, USA) following the manufacturer's standards. This test aims at the qualitative and semi-quantitative detection of capsular antigens $C$. neoformans and $C$. gattii in liquor and serum and detects a minimum of about $3.2 \mathrm{ng} / \mathrm{ml}$ of capsular antigens.

\section{RESULTS}

All 249 cloaca and crop samples were considered negative for Cryptococcus neoformans and C. gattii isolation. A variety of other fungi grew on the bird seed agar, but those were not further classified. In what concerns the antigenemia, most serum samples presented a homogeneous suspension of particles without visualization of lump formation after mixing with latex, and were thus considered negative. The only positive sample came from a wildlife pigeon and the title was low (1:2).

\section{DISCUSSION}

This is the first study performed in Brazil with the aim to isolate Cryptococcus neoformans and C. gattii from bird's digestive tract. Despite $C$. neoformans isolation being frequent in excreta from avian species (Mitchell \& Perfect 1995, Filiú et al. 2002, Kobayashi et al. 2005, Granados \& Castañeda 2005, Abegg et al. 2006), the fungus is hardly isolated from the digestive tract of those birds (Rosario et al. 2005, Cafarchia et al. 2006a,b), as seen in the present study. Rosario et al. (2005) isolated only $1.81 \%$ of $C$. neoformans from cloacal samples of pigeons, and Cafarchia et al. (2006a) did not obtain any positive results for $C$. neoformans or C. gattii in cloacal samples of 421 migratory birds. Cafarchia et al. (2006b) did not manage to recover either $C$. neoformans or $C$. gattii from any sample of digestive system tract segments of any dead bird of prey and obtained $2.2 \%$ of $C$. neoformans var. grubii from cloacal swabs.

It is possible that such low or nule isolation rate is due to bad growth conditions for the fungus, because of the birds' high temperature and the high concentration of ammonia in fresh excreta, alkalinizing the medium (Sorrel \& Ellis 1997). Mancianti et al. (2001) could not find C. neoformans or $C$. gattii in isolates of yeasts of 325 samples of fresh excreta of Psittaciformes.

The fast growth of contaminant fungi, especially Zygomycetes, makes it possible to obtain false-negative results (Swinne-Desgain 1975, Kobayashi et al. 2005). It is known that the number of colonies of $C$. neoformans and/or $C$. gattii is inversally proportional to the number of other yeast colonies contained in Petri plates (SwinneDesgain 1975).

The mechanism through which the excreta become infected is still uncertain (Sorrel \& Ellis 1997, Filiú et al. 2002). However, the development of $C$. neoformans in birds' excreta can be attributed to the large quantity of fungic cells in soil or air, dispersed by wind, which found a rich environment in excreta for their proliferation. It is widely known that non-infected pigeon excreta become infected when exposed to air containing aerosolubilized cells of $C$. neoformans (Casadevall \& Perfect 1998). Besides, when transferred to places with high environmental prevalence of $C$. gattii, koalas (Phascolarctos cinereus) without nasal colonization by Cryptococcus spp. become persistently colonized (Krockenberger et al. 2002). The results obtained in the present study, together with the claims made by the cited authors, confirm the assumption of environmental contamination of the excreta. Nevertheless, for a more precise analysis of this hypothesis it would also be necessary to collect samples from the environment, air, and food in order to identify the main environmental source of Cryptococcus spp. Furthermore, additional studies are required to evaluate relation of cloacal and crop colonization with host, virulence and pathogenicity of the agent (Krockenberger et al. 2002), thus demonstrating the real importance of these factors in the understanding of the relationship between Cryptococcus spp. and various avian species.

The latex agglutination test is usually used for diagnosing cryptococosis in humans, pets and birds (Medleau et al. 1990, Mitchell \& Perfect 1995, Raso et al. 2004). It demonstrates high sensitivity and specificity, and presents quick results (Medleau et al. 1990, Mitchell \& Perfect 1995, Casadevall \& Perfect 1998); however, rare negative results may be obtained when the disease is localized (Medleau et al. 1990).

No antigenemia was observed in most investigated birds, suggesting that Cryptococcus spp. do not invade the birds'organism, consequently discarding possible subclinical infections and the status of carrier. Negative results were also obtained for the antigenemia of dogs, cats, and 
koalas with nasal cavity colonization by $C$. neoformans demonstrating a low invasive capability of the fungus in immunocompetent animals (Malik et al. 1997, Connolly et al. 1999). The only animal with positive antigenemia had a low title. In this case, it is suggested that there was a systemic invasion or a localized infection by active penetration, which can occur in birds (Malik et al. 2003). As no detailed clinical exam and no necropsy were carried out in the animals in order to confirm or discard the presence of induced lesions by Cryptococcus sp., crypto-coccosis cannot be discarded in that specific animal. It is worth pointing out that this individual was a wildlife bird and that in such environment birds are exposed to a higher quantity of inoculum, because of the contamination of urban agglomeration with pigeon excreta. Birds kept in captivity were given a daily hygienic treatment and had a lower susceptibility to develop cryptococcosis or to contact the yeast.

\section{CONCLUSIONS}

The results obtained in the present investigation led us to suggest that Cryptococcus spp. are not endosaprobiotic in the avian digestive tract, and that their primary source might be the environment, and also that they find a favorable environment for their development in birds' excreta. Furthermore, the yeast has a low invasive capability in the species included in this study.

Acknowledgments.- We thank CAPES and Fundação Araucária for their financial support; IBAMA for having licensed the project; the trainees, technicians and employees of CETAS PUCPR/IBAMA; the Curitiba Zoo and the UFPR Veterinarian Hospital, especially Lucyene Giselle Popp Brasil Queiroz, for their invaluable help in carrying out the project.

\section{REFERENCES}

Abegg M.A., Cella F.L., Faganello J., Valente P., Schrank A. \& Vainstein M.H. 2006. Cryptococcus neoformans e Cryptococcus gattii isolated from the excreta of psittaciformes in a southern Brazilian zoological garden. Mycopathologia 161(2):83-91.

Bauwens L., Swinne D., Vroey C. \& Meurichy W. 1986. Isolation of Cryptococcus neoformans var. neoformans in the aviaries of the Antwerp Zoological Gardens. Mykosen 29(7):291-294.

Boekhout T., Theelan B., Dias M., Fell J.W., Hop W.C.J., Abeln E.C.A., Drome F. \& Meyer W. 2001. Hybrid genotypes in the pathogenic yeast Cryptococcus neoformans. Microbiol. 147:891-907.

Cafarchia C., Camarda A., Romito D., Campolo M., Quaglia N.C., Tullio D. \& Otranto D. 2006a. Occurrence of yeast in cloacae of migratory birds. Mycopathologia 161(4):229-234.

Cafarchia C., Romito D., latta R., Camarda A., Montagna M.T. \& Otranto D. 2006b. Role of birds of prey as carriers and spreaders of Cryptococcus neoformans and other zoonotic yeasts. Med. Mycol. 44(6):485-92.

Casadevall A. \& Perfect J.R. 1998. Cryptococcus neoformans. American Society for Microbiology Press, Washington, DC. 541p.

Connolly J.H., Krockenberger M., Malik R., Canfield P.J., Wigney D.I. \&
Muir D.B. 1999. Asymptomatic carriage of Cryptococcus neoformans in the nasal cavity of the koala (Phascolarctos cinereus). Med. Mycol. 37:331-338.

Filiú W.F.O.F., Wanke B., Agüena S.M., Vilela V.O., Macedo R.C.L. \& Lazera M. 2002. Cativeiro de aves como fonte de Crytococcus neoformans na cidade de Campo Grande, Mato Grosso do Sul, Brasil. Revta Soc. Bras. Med. Trop. 35(6):591-595.

Franzot S.P., Salkin I.F. \& Casadevall A. 1999. Cryptococcus neoformans var. grubii: separate varietal status for Cryptococcus neoformans serotype A isolates. J. Clin. Microbiol. 37:838-840.

Granados D.P. \& Castañeda E. 2005. Isolation and characterization of Cryptococcus neoformans varieties recovered from natural sources in Bogotá, Colombia, and study of ecological conditions in the area. Microb. Ecol. 49:282-290.

Know-Chung K.J., Boekhout T., Fell J.W. \& Diaz M. 2002. Proposal to conserve the name Cryptococcus gattii against $C$. hondurianus and C. bacillisporus (Basidiomycota, Hymenomycetes, Tremellomycetidae). Taxon 51:804-806.

Kobayashi C.C.B.A., Hasimoto e Souza L.K., Fernandes O.F.L., Brito S.C.A., Silva A.C., Sousa E.D. \& Silva M.R.R. 2005. Characterization of Cryptococcus neoformans isolated from urban environmental sources in Goiânia, Goiás, Brazil. Revta Inst. Med. Trop. 47(4):203207.

Krockenberger M.B., Canfield P.J. \& Malik R. 2002. Cryptococcus neoformans in the koala (Phascolarctos cinereus): colonization by $C$. $n$. var. gattii and investigation of environmental sources. Med. Mycol. 40:263-272.

Lazéra M.S., Cavalcanti M.A.S., Trilles L., Nishikawa M.M. \& Wanke B. 1998. Cryptococcus neoformans var. gattii: Evidence for a natural habitat related to decaying wood in a pottery tree hollow. Med. Mycol. 36:119-122.

Lazéra M.S., Salmito Cavalcanti M.A., Londero A.T., Trilles L., Nishikawa M.M. \& Wanke B. 2000. Possible primary ecological niche of Cryptococcus neoformans. Med. Mycol. 38:379-383.

Malik R., Wigney D.I., Muir D.B. \& Love D.N. 1997. Asymptomatic carriage of Cryptococcus neoformans in the nasal cavity of dogs and cats. J. Med. Vet. Mycol. 35:27-31.

Malik R., Krockenberger M.B., Cross G., Doneley R., Madill D.N., Black D., Mcwhirter P, Rozenwax A, Rose K, Alley M, Forshaw D, RusselBrown I, Johnstone A.C., Martin P., O'Brien C.R. \& Love D.N. 2003. Avian cryptococcosis. Med. Mycol. 41:115-24.

Mancianti F., Nardoni S. \& Ceccherelli R. 2001. Occurrence of yeasts in psittacines droppings from captive birds in Italy. Mycopathologia 153:121-124.

Medleau L., Marks M.A., Brown J. \& Borges W.L. 1990. Clinical evaluation of a cryptococcal antigen latex agglutination test for diagnosis of cryptococcosis in cats. J. Am. Vet. Med. Assoc. 196(9):14701473.

Mitchell T.G. \& Perfect J.R. 1995. Cryptococcosis in the era of AIDS 100 years after the discovery of Cryptococcus neoformans. Clin. Microbiol. Rev. 8(4):515-548.

Raso T.F., Werther K., Miranda E.T. \& Mendes-Giannini M.J.S. 2004. Cryptococcosis outbreak in psittacine birds in Brazil. Med.Mycol. 42:355-362.

Rosario I., Hermoso de Mendonza M., Déniz S., Soro G., Álamo I. \& Acosta B. 2005. Isolation of Cryptococcus species including $C$. neoformans from cloaca of pigeons. Mycoses 48:421-424.

Sorrell T.C. \& Ellis D.H. 1997. Ecology of Cryptococcus neoformans. Revta Iberoam. Micol. 14:42-43.

Swinne-Desgain D. 1995. Cryptococcus neoformans of saprophytic origin. Sabourandia 13:303-308. 